\title{
Energy demand and thermal comfort of HVAC systems with thermally activated building systems as a function of user profile
}

\author{
Katarzyna Pałaszyńska ${ }^{1,{ }^{*}}$, Karol Bandurski ${ }^{1}$, and Mieczysław Porowski ${ }^{1}$ \\ ${ }^{1}$ Poznan University of Technology, Faculty of Civil and Environmental Engineering, Institute of \\ Environmental Engineering, ul. Berdychowo 4, 60-965 Poznań, Poland
}

\begin{abstract}
Thermally Activated Building Systems (TABS) are a way to use building structure as a thermal energy storage. As a result, renewable energy sources may be used more efficiently. The paper presents numerical analysis of a HVAC system with TABS energy demand and indoor thermal comfort of a representative room in a non-residential building (governmental, commercial, educational). The purpose of analysis is to investigate the influence of a user profile on system performance. The time span of the analysis is one year - a typical meteorological year. The model was prepared using a generally accepted simulation tool - TRNSYS 17. The results help to better understand the interaction of a user profile with TABS. Therefore they are important for the development of optimal control algorithms for energy efficient buildings equipped with such systems.
\end{abstract}

\section{Introduction}

Thermally activated ceilings (a part of TABS - Thermally Activated Building Systems) is a solution making it possible to shift in time thermal loads (concerning both heating and cooling) by means of using the accumulation potential of construction elements. It also makes it possible to change thermal comfort by directly impacting the average temperature of internal surfaces.

Lines with water or air are embedded in the ceiling and act as heat exchangers transferring heat to and from occupied zone and storing thermal energy TABS do not only transfer or receive heat (mainly by radiation [1]) but also affect thermal characteristics of a building. The most common TABS solution is ceiling activation.

The development of simulation models is necessary to create design guidelines and system controls. Adjusting a system with TABS is difficult due to the high thermal inertia resulting from a significant heat capacity.

${ }^{*}$ Corresponding author: katarzyna.palaszynska@put.poznan.pl 


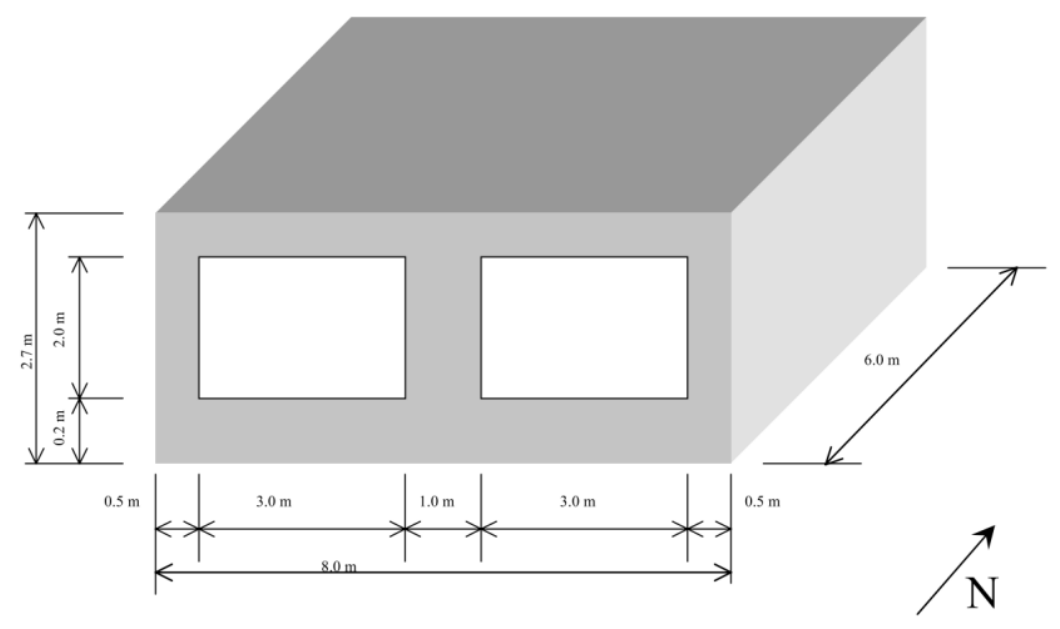

Fig. 1. The modeled room [9].

Research on systems with thermally activated ceilings have been conducted for about 20 years. Olsen et al. [2-4] conducted research on modeling TABS and proposed a dimensioning method for thermally activated ceilings. This research lead to the development of the ISO 11855-4:2012 standard [6]. On the other hand Rijksen et al. [5] conducted simulation and empirical research on TABS, providing general guidelines for determining the required cooling capacity for an entire office building with such a system, located in a temperate climate. Lehmann et al. [7] demonstrated a significant impact of the adopted hydraulic system and the applied control strategy on the efficiency of using the energy from a system with thermally activated ceilings. Saelens et al. [8] analyzed the occupant behaviour impact on the energy efficiency of TABS during the cold season for the climate conditions of Belgium. The assessment parameter for the heat comfort of the simulation model was temperature in a given room.

The presented paper solves two optimization problems of a HVAC system with TABS. Solution is based on one-zone office model. The optimization criterion for the first problem was thermal comfort and for the second problem - it was the minimum primary energy demand with constraints concerning thermal comfort. The decision variable of both optimization problems was the supply water temperature of a thermally activated ceiling.

\section{Model and assumptions}

The analyzed object is a room (Fig.1) (in an office building) with the following parameters:

- $\quad$ dimensions: area $=48.0\left[\mathrm{~m}^{2}\right]$, height $=2.7[\mathrm{~m}]$;

- exterior wall: facing South $(\mathrm{S})$, area $=2.6\left[\mathrm{~m}^{2}\right]$, heat transfer coefficient $\mathrm{U}=0.35\left[\mathrm{~W} /\left(\mathrm{m}^{2} \mathrm{~K}\right)\right]$;

- exterior wall windows: two pieces $=2.0 \times 3.0[\mathrm{~m}]\left(12\left[\mathrm{~m}^{2}\right]\right)$, heat transfer coefficient $\mathrm{U}=2.89\left[\mathrm{~W} /\left(\mathrm{m}^{2} \mathrm{~K}\right)\right]$;

- infiltration: $0.1[1 / \mathrm{h}]$;

- ventilation (hygienic needs): $2.0[1 / \mathrm{h}]$, supply temperature $22^{\circ} \mathrm{C}$.

The modeled room is based on a case study from RADTEST [9]. The simulation was performed with TRNSYS 17 [10]. The used building model was TRNSYS, type 56 using the mode of the most detailed calculation for heat exchange by radiation: 
- direct radiation through an external partition - geometric distribution;

- diffuse and long wave radiation - based on view factors.

Other assumptions (as fixed parameters) in simulation models of the performed analysis:

- weather data: Typical Meteorological Year for Poznań, MeteoNorm Reference Year;

- comfort condition: category B acc. to EN 15251, indoor air temperature: from $20^{\circ} \mathrm{C}$ to $24^{\circ} \mathrm{C}$;

- thermal comfort model: Fanger acc. to ISO 7730, additional assumption: constant air velocity $=0.1[\mathrm{~m} / \mathrm{s}]$, clothing $=1$ [clo], metabolism $=1[\mathrm{met}]$;

- heat transfer with other zones of the building was neglected (adiabatic partition wall);

- zone heat capacity: air heat capacity added to room equipment heat capacity estimated as five times the heat capacity of the air alone acc. to the rule of thumb in building performance simulations;

- type of building -internal heat gains patterns: governmental, commercial, educational (Fig. 2).

Governmental

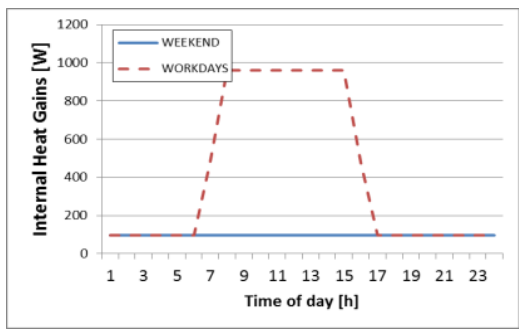

Commercial

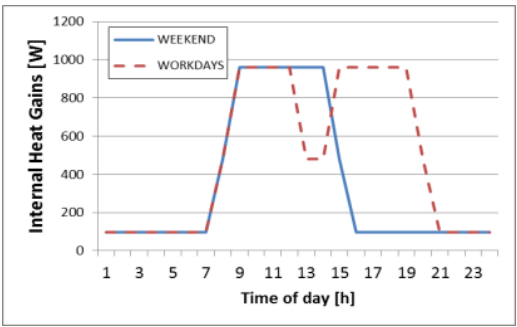

Educational

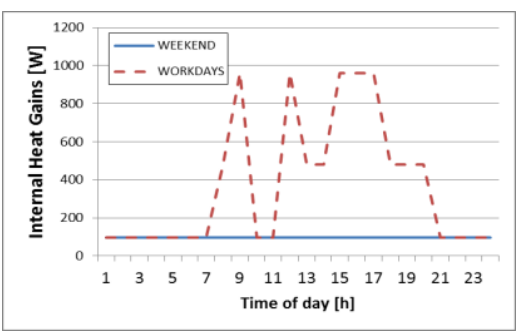

Fig. 2. Internal heat gains patterns.

Values of internal heat gains are based on ISO 13790, annex G. The gains are divided into radiation $(30 \%)$ and convection $(70 \%)$ heat gains acc. to human body's thermal balance and [11].

\section{Optimization criteria}

There are two optimization problems:

- First optimization criterion: 
○ decision variables: TABS supply water temperature $t_{\text {in }} \epsilon<20,24>{ }^{\circ} \mathrm{C}$;

optimization criterion: minimum number of hours of thermal discomfort per year $=$ thermal comfort of PMV $\epsilon<-0.5,0.5>$ (minimum number of hours of thermal discomfort).

- Second optimization criterion:

○ decision variables: TABS supply water temperature, $\mathrm{t}_{\text {in }} \epsilon<20,24>{ }^{\circ} \mathrm{C}$;

$\circ$ constraints: PMV $\epsilon<-0.5,0.5>$;

$\circ$ optimization criterion: minimum annual primary energy demand $\mathrm{E}_{\mathrm{p}}=\min$.

Decision variables for optimization models are presented in Table 1.

Table 1. Decision variables for optimization models.

\begin{tabular}{|c|c|c|}
\hline Designation & $\begin{array}{l}\text { TABS supply water } \\
\text { temperature } t_{i n}\end{array}$ & $\begin{array}{c}\text { Type of building/user } \\
\text { profile }\end{array}$ \\
\hline G_20 & 20 & \multirow{5}{*}{$\begin{array}{l}\text { office in a } \\
\text { governmental building }\end{array}$} \\
\hline G_21 & 21 & \\
\hline G 22 & 22 & \\
\hline G_23 & 23 & \\
\hline G_24 & 24 & \\
\hline C_ 20 & 20 & \multirow{5}{*}{$\begin{array}{l}\text { office in a commercial } \\
\text { building }\end{array}$} \\
\hline C 21 & 21 & \\
\hline C 22 & 22 & \\
\hline C 23 & 23 & \\
\hline C 24 & 24 & \\
\hline E 20 & 20 & \multirow{5}{*}{$\begin{array}{l}\text { office in an educational } \\
\text { building }\end{array}$} \\
\hline E 21 & 21 & \\
\hline E 22 & 22 & \\
\hline E 23 & 23 & \\
\hline E 24 & 24 & \\
\hline
\end{tabular}

The usable energy demand (usable heat and usable cooling) and the primary energy demand were calculated based on the zone heat balance and the following equations:

$$
\begin{gathered}
0=\frac{d C_{\text {zone }}}{d t}+Q_{\text {inf }}(t)+Q_{\text {vent }}(t)+Q_{\text {gain_conv }}(t)+Q_{\text {sun_air }}(t)+Q_{\text {surf_conv }}(t) \\
+Q_{H-A C_{\_} a i r}(t) \\
Q_{\text {system }}(t)=Q_{\text {water_TABS }}(t)+Q_{H-A C_{-} a i r}(t) \\
E_{p}=\sum_{i} \frac{w_{i}}{\eta_{i, t}} \cdot Q_{\text {system }}(t)
\end{gathered}
$$

where:

$t$ - time;

$C_{\text {zone }}$ - zone heat capacity (air, furniture, equipment);

$Q_{\text {inf }}$ - heat supplied by infiltration;

$Q_{\text {vent }}$ - heat supplied by ventilation (in this case $T_{\text {vent-air }}=22^{\circ} \mathrm{C}$ ); 
$Q_{\text {gain_conv }}$ - heat supplied by convection through internal heat sources;

$Q_{\text {sun_air }}$ - heat gains of the solar energy which, directly after passing through a window, are immediately transferred as convective heat gains into air;

$Q_{\text {surf_conv }}$ - heat coming from zone partition surfaces to air by convection;

$Q_{H-A C_{-} a i r}(t)$ - heat supplied to the zone by the air line of a HVAC system (in TRNSYS corresponding to $=-Q_{\text {SENS }}$ which is negative in case of the demand for heating to a desired air temperature, and positive in case of the demand for cooling to a desired air temperature);

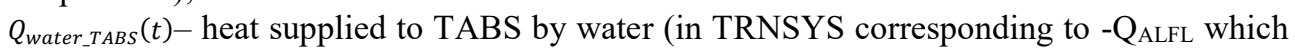
is negative in case of water heating the ceiling, i.e. $T_{\text {inlet }}>T_{\text {outlet }}$, and positive in case of water cooling the ceiling i.e. $T_{\text {inlet }}<T_{\text {outlet }}$;

$Q_{\text {system }}(t)$ - heat energy demand of the whole comfort system (air conditioning and HVAC excluding ventilation)

$E_{p}$ - annual primary energy demand for a HVAC system

$w_{i}$ - input coefficient of the non-renewable primary energy for the production and supply of an energy carrier (or the final energy) $\left(\mathrm{i} \rightarrow{ }_{\mathrm{H}}\right.$ relates to heat, $\mathrm{i} \rightarrow_{\mathrm{C}}$ relates to cold); $\mathrm{w}_{\mathrm{H}}=1.1$ and $\mathrm{w}_{\mathrm{C}}=3[12]$

$\eta_{i, t}-$ seasonal average total efficiency of production (conversion): $\mathrm{i} \rightarrow{ }_{\mathrm{H}}$ of heat for heater blowers, $\mathrm{i} \rightarrow{ }_{\mathrm{C}}$ of cold for intercoolers); $\eta_{\mathrm{H}, \mathrm{t}}=0.81$ and $\eta_{\mathrm{C}, \mathrm{t}}=1.9[12]$

\section{Calculation results and interpretation}

For the first optimization problem with the optimization criterion being the thermal comfort, results of the simulation are presented in Table 2 (dark fields: 0 hours of discomfort; the brighter the field, the more hours of discomfort). The optimization criterion is the minimum number of hours of discomfort (decreasing preference criterion). The optimal variants for different types of buildings (internal heat gains patterns) are:

- Governmental: minimum number of hours of discomfort $\mathrm{n}=102 \mathrm{~h}$ for $\mathrm{t}_{\mathrm{in}}=+22^{\circ} \mathrm{C}$ - constant throughout the year $\left(\max n=558 \mathrm{~h}, \mathrm{t}_{\mathrm{in}}=24^{\circ} \mathrm{C}\right)$

- Commercial: minimum number of hours of discomfort $\mathrm{n}=119 \mathrm{~h}$ for $\mathrm{t}_{\mathrm{in}}=+21^{\circ} \mathrm{C}-$ constant throughout the year $\left(\max n=770 \mathrm{~h}, \mathrm{t}_{\text {in }}=24^{\circ} \mathrm{C}\right)$

- Educational: minimum number of hours of discomfort $\mathrm{n}=79 \mathrm{~h}, \mathrm{t}_{\mathrm{in}}=+22^{\circ} \mathrm{C}-$ constant throughout the year $\left(\max n=363 \mathrm{~h}, \mathrm{t}_{\mathrm{in}}=24^{\circ} \mathrm{C}\right)$

It should be noted that for all three types of buildings - optimal variants are in the temperature range of $t_{\text {in }}=+21$ to $22^{\circ} \mathrm{C}$.

For the second optimization problem with the optimization criterion being the minimum annual primary energy demand $\left(\mathrm{E}_{\mathrm{p}}=\mathrm{min}\right.$.), results of the simulation are presented in Table 3. The optimal variants for different types of buildings (internal heat gains patterns) are:

- Governmental: $\mathrm{E}_{\mathrm{p}_{-} \min }=1720 \mathrm{kWh} / \mathrm{a}$ for tin $=+20^{\circ} \mathrm{C},\left(\mathrm{E}_{\mathrm{p}_{-} \max }=4364[\mathrm{kWh} / \mathrm{a}]\right.$ for $\operatorname{tin}=+24^{\circ} \mathrm{C}$ )

- Commercial: $\mathrm{E}_{\mathrm{p}_{-} \min }=2093 \mathrm{kWh} / \mathrm{a}$ for tin $=+20^{\circ} \mathrm{C},\left(\mathrm{E}_{\mathrm{p}_{-} \max }=5370[\mathrm{kWh} / \mathrm{a}]\right.$ for $\mathrm{t}_{\text {in }}=+24^{\circ} \mathrm{C}$ )

- $\quad$ Educational: $\mathrm{E}_{\mathrm{p}_{-} \min }=1496 \mathrm{kWh} / \mathrm{a}$ for tin $=+20^{\circ} \mathrm{C},\left(\mathrm{E}_{\mathrm{p}_{-} \max }=4039[\mathrm{kWh} / \mathrm{a}]\right.$ for $\left.\mathrm{t}_{\text {in }}=+24^{\circ} \mathrm{C}\right)$ 
Table 2. Number of hours of discomfort for different types of buildings.

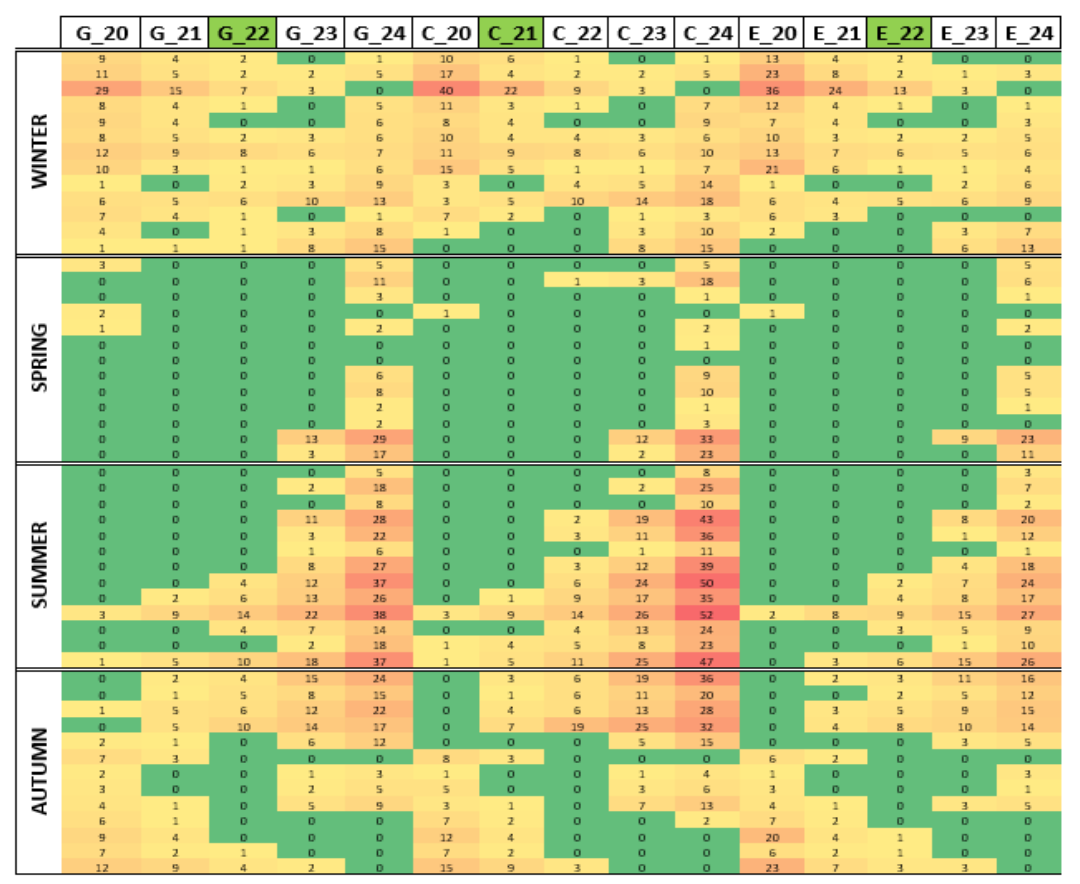

Table 3. Calculation results of the annual energy demand for a HVAC system with TABS: a) useful heat, b) useful cold, c) primary energy, d) percentage difference between optimal variant and others.

a)

\begin{tabular}{|r|r|r|r|}
\hline \multirow{2}{*}{$\begin{array}{c}\text { T_inlet } \\
{\left[{ }^{\circ} \mathrm{C}\right]}\end{array}$} & \multicolumn{4}{|c|}{ Q_heat [kWh/a] } \\
\hline 20 & \multicolumn{1}{|c|}{$\mathrm{C}$} & $\mathrm{E}$ \\
\hline 21 & 199 & 130 & 209 \\
\hline 22 & 72 & 41 & 76 \\
\hline 22 & 18 & 9 & 19 \\
\hline 23 & 4 & 2 & 4 \\
\hline 24 & 0 & 0 & 0 \\
\hline
\end{tabular}

c)

\begin{tabular}{|r|r|r|r|}
\hline T_inlet & \multicolumn{3}{|c|}{$E[k W h / a]$} \\
\cline { 2 - 4 }$\left[{ }^{\circ} \mathrm{C}\right]$ & $G$ & $\mathrm{C}$ & $\mathrm{E}$ \\
\hline 20 & 1728 & 2093 & 1496 \\
\hline 21 & 2144 & 2721 & 1878 \\
\hline 22 & 2777 & 3530 & 2487 \\
\hline 23 & 3541 & 4433 & 3234 \\
\hline 24 & 4364 & 5370 & 4039 \\
\hline
\end{tabular}

b)

\begin{tabular}{|r|r|r|r|}
\hline T_inlet & \multicolumn{3}{|c|}{ Q_cool [kWh/a] } \\
\cline { 2 - 4 }$\left[{ }^{\circ} \mathrm{C}\right]$ & $G$ & \multicolumn{1}{|c|}{$\mathrm{C}$} & $\mathrm{E}$ \\
\hline 20 & 923 & 1214 & 768 \\
\hline 21 & 1296 & 1688 & 1124 \\
\hline 22 & 1743 & 2228 & 1559 \\
\hline 23 & 2239 & 2806 & 2045 \\
\hline 24 & 2764 & 3401 & 2558 \\
\hline
\end{tabular}

d)

\begin{tabular}{|r|r|r|r|}
\hline T_inlet & \multicolumn{3}{|c|}{$E[\%]$} \\
\cline { 2 - 4 }$\left[{ }^{\circ} \mathrm{C}\right]$ & $\mathrm{G}$ & $\mathrm{C}$ & $\mathrm{E}$ \\
\hline 20 & $-38 \%$ & $-23 \%$ & $-40 \%$ \\
\hline 21 & $-23 \%$ & $0 \%$ & $-25 \%$ \\
\hline 22 & $0 \%$ & $30 \%$ & $0 \%$ \\
\hline 23 & $28 \%$ & $63 \%$ & $30 \%$ \\
\hline 24 & $57 \%$ & $97 \%$ & $62 \%$ \\
\hline
\end{tabular}

\section{Conclusion}

Based on the one-zone office model the simulation analysis and optimization task have been performed. The following conclusions can be defined: 
- type of building (internal heat gains patterns) significantly affects the optimal comfort temperature of the TABS supply water. For the analyzed types of buildings, the optimum comfortable temperature equals $t_{\text {in }}=+21$ to $22^{\circ} \mathrm{C}$

- the comfortably optimal TABS supply water temperature is a function of parameters of the external climate (seasons). The analysed temperature range of $\mathrm{t}_{\mathrm{in}}+20$ to $24^{\circ} \mathrm{C}$ is the most suitable for spring and summer

- type of building (internal heat gains patterns) significantly affects the annual primary energy demand. For the energetically optimal variants, the annual primary energy demand for a Commercial building $(2093 \mathrm{kWh} / \mathrm{a})$ is $40 \%$ higher than the same demand for an Educational building (1496 kWh/a)

- energetically optimal TABS supply water temperature equals $t_{\text {in }}=+20^{\circ} \mathrm{C}$ for all of the analyzed type of buildings.

- having analyzed the two optimization criteria (concerning comfort and energy), the operationally optimal TABS supply water temperature equals $t_{\text {in }}=+21^{\circ} \mathrm{C}$.

- changing temperature of TABS supply water, relative to comfortably optimal TABS supply water temperature, has a significant effect on energy consumption in the range of $-38 \%$ to $+57 \%$ for governmental, in the range of $-23 \%$ to $+97 \%$ for commercional and $-40 \%$ to $62 \%$ for educational (Table $3 \mathrm{~d}$ )

The undertaken research does not cover the whole subject. Further studies will extend the assumptions of this simulation model. This particularly applies to:

- $\quad$ taking into account a model with more zones (not only one-zone) ;

- changing thermal insulation and heat capacity of external wall;

- introducing a (adjustable/fixed) shading;

- introducing ventilation with a variable air flow (depending on requirements) DCV (Demand Controlled Ventilation);

- taking into account changes in clothing (clothing insulation) throughout the year;

\section{References}

1. J. Romaní, A. De Gracia, L.F. Cabeza, Energy Build. 127 (2016)

2. B.W. Olesen, K. Sommer, B. Düchting, ASHRAE Trans. 108 (2000)

3. P. Weitzmann, E. Pittarello, B.W. Olesen, Proceedings of the 8th symposium on Building Physics in the Nordic Countries (2008)

4. B. Olesen, ASHRAE J. 50 (2008)

5. D.O. Rijksen, C.J. Wisse, A.W.M. van Schijndel, Energy Build. 42, 3 (2010)

6. ISO 11855-4 Building Environment Design - Design, Dimensioning, Installation and Control of Embedded Radiant Heating and Cooling Systems - Part 4: Dimensioning and calculation of the dynamic heating and cooling capacity of Thermo Active Building Systems (2012)

7. B. Lehmann, V. Dorer, M. Gwerder, F. Renggli, J. Tödtli, Appl. Energy 88, 1 (2011)

8. D. Saelens, W. Parys, R. Baetens, Build. Environ. 46 (2011)

9. M. Arechmann, G. Zweifel, RADTEST - Radiant Heating and Cooling Test Cases (2003)

10. S.A. Klein et al., TRNSYS 17: A Transient System Simulation Program (2009)

11. M.H. Hosni, B.W. Jones, H. Xu, ASHRAE Trans. 105 (1999)

12. M. Porowski, Ciepłownictwo, Ogrzewnictwo, Wentylacja 42, 3 (2011) 